\title{
Saudi Nationals Wasting Time at Work in Private Organizations and the Perspective of Islam
}

\author{
Dr. AbdulwahabShmailan \\ Jubail Industrial College-Saudi ArabiaP.O:10099, ZIP Code:31961
}

\begin{abstract}
The purpose of paper to analyze workers waste time in private organizations around the world and especially for Saudi national staff in Western Province of Saudi Arabia. The study includes the perspective of authors in western countries and the theocratic view of Islam on time. The Quran, the teachings of Prophet Mohamed and Muslim scholars including the Hadiths will examine the role of Islam in time management in comparison to western ideals
\end{abstract}

Key Words:Time Management, waste time, Islam, Muslim, private organization, Saudi national staff.

\section{Introduction:}

Worker productivity around the world and in Saudi Arabia is a challenging issue. In a report conducted by McKenzie Global Institute of workers found they spend average of 2.6 hours per day at work reading and answering emails(McKenzie, 2012). Over a period of one year this is 27 days.

In their survey they focused on people who were "knowledge workers" that includes, managers, sales people, scientists whose jobs are interact with other employees, customers, and suppliers. These employees make complex decisions using their knowledge and judgment. Daily they spend 28\% of their time on email.

Islam, in the Qu'ran and Hadith's, talks about the importance of time in every Muslim's life. Saudi Arabia, being the home of Islam and the protector of the two holy mosques in Mecca and Madina, should be a leader in this area. Islamic teaching suggests that each Muslim conduct his or her affairs properly and in an effective and efficient manner. Prophet Mohammed says: "On the day of Resurrection, the feet of man will not move away till he is questioned about four matters: how he spent his lifetime, how he spent his youth, from where he acquired his wealth and how he spent it, and what he did with his knowledge." (Attermidthi). This article will further discuss the importance to managing time in the context of Islam and Saudi Arabia

\section{The main objectives:}

-To determine how many productive hours per day Saudi national staff actually work at private companies in Saudi Arabia.

-To show the organization what things employees wasted their time and how can they control it.

-To review academic research and to produce a literature review of what Islam says about wasting time, including an examination of the holy Quran , Prophet Mohammed and religious scholars.

-To create solutions and or recommendations directly related to the result of the study for private and government organizations in Saudi Arabia.

\section{Research questions:}

Q1.Find out how many hours do the Saudi national staff waste time at their work every day on personal business in private organizations in Saudi Arabia?

Q2. What are the perspectives of Islam perceived from Quran, Prophet Mohammed and religious scholars on time management?

\section{Research Methodology:}

The research conducted used quantitative methodology by means of questionnaire survey. The population for the research was private companies operating in Saudi Arabia. Data was collected using by distributing a questionnaire and manually performing the analysis.

\section{Sample Used:}

Sample used for Saudi employees working in private organizations. The participants were selected randomly from different private industries including: private hospitals, telecommunications, insurance companies, banks, private education and manufacturers. The respondent a diverse group with different kinds of experiences and position; including low, middle, and high level management. 


\section{Significance of the study:}

The study will be beneficial to academics, and researchers in developing further research into the private and government organizations in Arab and Muslim Countries.

The study will benefit private and government organizations by learning how to encourage their staff to be productive at work.

The contribution can be of academic relevance but in addition can be of a practical nature as the findings can be helpful for governments and organizations to know about how many hours their staff wasted their time at work.

To clarify how Islam encourages productivity at work for everybody.

To show the researcher and academics how Islam cares about time and encourages people not to waste time.

Academic research on time management can benefit from understanding the theoretical concepts of Islam and how it relates to the study.

\section{Literature Review:}

Time has had many definitions and fundamental differences as to its meaning. For instance, time has been described as "time nothing more than the occurrence of events in sequence, one after another" (Olpin and Hessen, 2012, p.167), and "a resource that, when lost or misplaced, is gone forever" (Kerzner, 2009, p.286).

Becker and Mustric (2008) divide time into two categories: quantitative and qualitative. It can be specified that "quantitative time is seen to represent time as quantities, that is, time can be measured and counted into seconds, minutes, days, weeks, months, and years" (Wu, 2009, p.5). Qualitative time, on the other hand, is associated with a meaning of an activity the time is spent on.

Similar to the concept of time, there are varying opinions amongst secondary data authors regarding the definition and role of time management. For instance, it has been noted that "time management is about taking charge, carefully, consciously, purposefully - not shrinking from difficulties, but engaging them" (Kristan, 2010). Moreover, some secondary data authors also note that "time management is not an end itself. It is the means to an end. When linked with setting and meeting goals it provided a way of getting significantly high performance out of individuals and others with whom they come into contact" (Pearson and Thomas, 2010, p.49). One definition of time management describes it as being "the process of skillfully applying time to finish and perfect a specific activity within time constraint" (Harris, 2008, p.22). There really is not a single definition of time that fully captures all aspects of the concept.

Marquis and Huston (2009), on the other hand, disagree with the term of time management, and argue that time cannot be managed in any ways, but rather individuals can manage events in their lives in relation to time.

At the same time, it has been warned by some secondary data authors that "time management must not be seen as only concerned with packing more activity on the available time, though this may be part of it; it must be in ensuring that objectives are met" (Forsyth, 2010, p.13). Moreover, it has also been stated that "time management is not about creating more time but rather about making the best use of the time we have" (Hansen, 2011, p.3).

For instance it has been stated that "when we manage our time more effectively and efficiently, we reduce stress and frustration, we become more confident, and we feel better" (Mancini, 2007, p.viii). Moreover, some secondary data authors convincingly argue that "with proper planning and some self-discipline, many urgent matters disappear altogether or, when they do surface, your planning and discipline makes them less urgent and easier to deal with" (Rivera, 2007, p.51).

Moreover, authors state that "the benefits of time management are many. Rather than running around in a state of frenzy, you feel a sense of empowerment from getting things done and having the time to enjoy life's simple pleasures" (Seaward, 2011, p.134).

Furthermore, the additional advantages of time management have been highlighted by secondary data authors as being more productive (Green and Skinner, 2005, Alexander and Dobson, 2008), having more energy to accomplish tasks (Limoncelli, 2006, Becker and Mustric, 2008) feeling less stressed (Bhugra and Howes, 2007, Brott, 2008), possibility to pursue personal interests, getting more things done (Green and Skinner, 2005) relating to others in more positive manner (Bhugra and Howes, 2007), and feeling better about self (Brott, 2008).

Secondary data authors stress that time management principles can be and have to be mastered by everyone regardless the nature of the their employment, age, religion or any other demographic or other variables. Namely, it has been said that "given the right intention, and motivation, it is possible for anyone to improve their time utilisation and to do so markedly of you have not thought about it recently" (Forsyth, 2010, p.8).

Time management in business and government is effectively using time to get the work done. If time is lost, it will slow the production process. There can be a number of reasons for poor time management including 
unorganized employees, design flaws or specifications, error in production planning. There could also be other administrative flaws such as bad working conditions, poor maintenance, old technology, lack of supplies, ill employees and other reasons including neglect or inaction.

According to a Web survey of average workers by American Online and Salary.com (Dan, 2005), the average American worker wastes over 2 hours each day. This does not include lunch. The internet is the biggest culprit with $44 . \%$ of Americans responding it was their major time waster. If American employees do waste on average 2.09 hours a day of time at work that adds up to $\$ 759$ Billion that American organizations pay for employee salaries for which the companies receive no clear benefit. Another major cause of time wasting is socializing with co-workers answered by $23.4 \%$. What could be the cause of employees wasting time? The survey indicated that $33.2 \%$ of respondents say they don't have enough work to do and $23.4 \%$ say they feel underpaid

\subsection{Corporate Organizations and Internet Usage:}

Gaudin(2009) companies that let employees have access to Facebook at work, there is a $1.5 \%$ drop in performance. Many organizations feel , 72\%, that employees using social networking is actually a threat to the organization (Shroeder, 2010). As a result, in another study by Robert Half Technology, over "54\% of U.S. companies prohibit all workers from using sites like Facebook during working hours (Gaudin, 2009). A UK study of over 3500 companies found that over 233 Million hours are wasted by employees every month by using social networking sites (Facebook costs Business,2007). Many employers are blocking employees from using Facebook. In a study conducted in Portsmouth their staff of 4500 accessed Facebook 270,000 times a month for a total of 572 hours wasted which is over 71 work days in a month (Kisiel,2009).

Not only is time wasted in organizations that allow there employees to use social media sights, but the computer system itself can be compromised by malware, or malicious software. In a report by Sophos (2010), there is an increase in malware on popular sites like Twitter, MySpace, Facebook and Linkedin. There also has been an increase of spam that users of the networking sites have received. In one year, 2010 there was an increase of $70.6 \%$ over the previous year (Shroeder, 2010).

In a 2009 survey, 24\% of SMBs reported having been affected by employees using peer-to-peer networking sites; and $32 \%$ by workers who downloaded media (Webroot,2010). Even companies that strongly believed they devoted sufficient resources toinformation security reported successful attacks from viruses $(60 \%$ of respondents),spyware (57\%), and phishing (47\%). Security breaches against SMBs are particularlytroublesome because many of them lack the resources to adequately contain and recover from attacks.

Clearly, these statistics demonstrate that personal Internet use by employees on company time is a problem. However, the question still remains as to how the extensive overuse of the Internet for non-work related purposes affects a business. Lost productivity affects a business and its employees on several different levels. To begin, an unproductive business is unable to pay its employees as high of wages as a productive business (Cashell, 2004). The working conditions in a productive business also differ than those of an unproductive business. Productive workplaces are more likely to involve the employees and acknowledge the efforts and the results of the employees (Hartshorn, 1997)

\subsection{Time Wasting Web Sites:}

In a more recent study in early 2012 by Salary.com (Gouveia, 2012) they surveyed 3200 people between February and March 2012 to find out their reactions to time wasting. The study found that the following sites were where employees wasted the most time. Facebook was the number one site mentioned with over 850 Million subscriber's world wide.

\section{Most Popular Time-Wasting Websites}

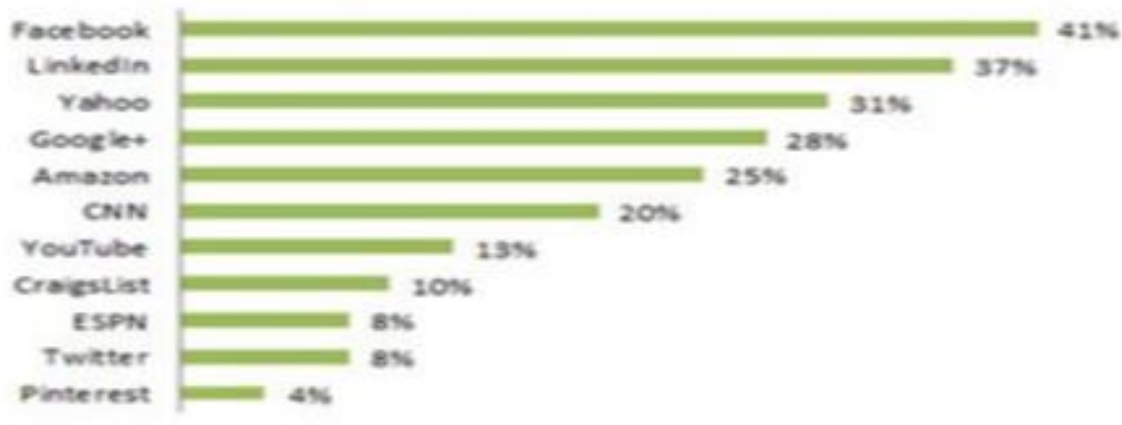


Is all this wasting of time at the workplace really impacting productivity? With all this talk of "wasting time" during work by checking Facebook, chatting with coworkers, etc., it's a worthwhile question to ask: are those things truly time-wasters? Respondents of the 2012 Salary.com survey overwhelmingly (71\%) said that taking short breaks during the work day actually helped them. Contrarily, the Mckinzy report suggest that time wasting alone in the US causes employers \$759 Billion annually(Dan,2012)

\subsection{Implications for Saudi Arabia:}

There has been little study conducted on the impact of Time Wasting in the Saudi workplace and the impact it has on worker productivity. They cited the threat the US is experiencing in reduced productivity due to employee time wasting on the internet. Many businesses have attempted to curb with Internet use by implementing policies and monitoring programs. Yet, the problem remains. In Saudi Arabia they believe part of the solution is the Censorship of non-work related websites can result in a more productive workplace. With the invention of devices like Smart phones employees still may be able to access unproductive sites in the workplace.

To have a clearer picture of the loss of productivity in the work place it would be beneficial to conduct a survey like to conduct a survey of Saudi employees to determine how much they do waste time at work on the internet and other activities. Censorship is only part of the problem. There may be other activities that are causing loss of productivity that need to be addressed as well.

\subsection{Theoretic view of Islam:}

The Koran says that there are many blessings that the God gives human and time is one of them. One passage talks about "... and if ye would count the bounty of Allah, ye could not reckon it" (Surat Ibrahim, 34). The blessing of time is mentioned in many Qu'anic Ayahs. Another reference in the Quran says that Allah says: "And maketh the sun and the moon, constant in their courses, to be of service to you, and hath made of service unto you the night and the day "( Surat Ibrahim, 33). So according to the Quran, one of the gifts God gave to man was the gift of time.

The five pillars of Islam also have time orientation. They are:

1. Shahadah, profession of faith. One god "There is no God but God and Muhammad is the Messenger of God".

2. Salah, prayer. Individuals have a direct relationship with God. Each person turns to Makah when they pray and there are prayers five times a day: dawn, noon, mid-afternoon, sunset and evening.

3. Zakat, almsgiving. Yearly the Muslim has to give 2.5 percent of their net worth minus expenses and family obligations.

4. Sawm is fasting during the holy month of Ramadan. Fasting is an exercise whereby one's sensitivity is heightened to the sufferings of the poor.

5. Hajj is the pilgrimage to Makah that all Muslims must attempt once in their lifetime.

The first pillar is only done once in a person's life and that is to make a commitment to god. Regarding the Salah, or prayers Allah told Muhammad that " (Surat An-nisa, 103) Worship at fixed hours hath been enjoined on the believers." Prayers have to be performed within specific times. Muslims have a basis of time management for prayers that can also be used for managing time in the rest of their day. In the Qur'an says that "(Surat Aljumaah,62) And when prayer is ended, then disperse in the land an seek in Allah's bounty, and remember All much, that ye will be successful. After Muslim's finish prayers, "Once Muslims finish their prayers they can pursue their livelihood by means of trade and other ways of satisfying their needs. Followers are rewarded if they manage their prayer times successfully. This is a great incentive for Muslims to manage their time effectively.

In Saudi Arabia, all businesses shut down during the day for the five prayers of the day. The morning prayer is performed at dawn so those on certain shifts may have to stop work to pray. The most common prayers done at work are the mid-day and afternoon prayers which last 30 minuteseach. Meetings have to be scheduled to take into account the prayers. Any meeting in progress will have to break for the prayer. This can aid in good time management.

There are also informal references to time associated to honoring god during the day. Giving praise at the beginning and the end the day is an example. (SuratAl-Room,17) So glory be to Allah when ye enter the night and when ye enter the morning. Another reference talks about at noon and at mid-afternoon. Unto Him be praise in the heavens and the earth - and a sun's decline and in the noonday. ( Surat Al-Room,17)

Zakat and Ramadan also have specific times allotted. Zakat must be paid. Pay the thereof upon the harvest day. When the harvest comes in "pay the Zakat due on the crop on the very day of harvest." (Surat AlAn'aam, 141). Ramadan is a fasting month that is timed to the sighting of the crescent moon. Much of Islamic 
time is based on the crescent moon. The Qur'an references the use of crescent moons.They asked the(Muhammad), of new moons. Say: They are fixed for mankind and the pilgrimage." The Islamic calendar, based on the moon, is used in most Muslim countries. The crescents "they are signals by which people know when to fast or break their fast and when to perform Hajj." (Al-Baqra,189)

Sunnah literature also discuses the importance of time and that it is a blessing from God. In one passage the Prophet says: "Health and leisure time are two blessings on which a lot of people are cheated. " (SahihAlbuchari, P.1232) Futher this Hadith say that " Only a few benefit those blessings. For example some people are healthy, but are not occupied with earning their living. Others want to be rich, but are not healthy enough to work for it. If they do not have health or the desire to seek wealth, they are absolute losers.

Time is also mentioned in the Day of Resurrection in another Hadith in which the Profhet said: "On the day of Resurrection the feet of the son of Adam (man) will not move away till he is questioned about four matters: How he spent his lifetime, how he spent his youth, from where he acquired his wealth and how he spent it, and what he did with his knowledge." (Tarmidthi) The Prophet was also very careful about his usage of time. In a hadith Ali Ibn-Abi-Taalib indicated that "When he gets home, he divides his time into three portions: one for Allah, one for his family and one for himself, and he divides his own portion between himself and the people" (Tarmidthi)

The Prophet also talked about the importance of balancing time in the life of a Muslim. "A wise person - if not out of his mind - has to apportion his time: time for praying to his Lord, time for questioning himself, time for reflecting on Allah's creation and time for his food and drink.". He also said regarding balance "Give your body its right, your eyes their right, your guests their right, and your wife her right. "(SahihAlbuchari, p341).

Finally in a Hadith by Ibn-Abbas, the Prophet talks how one should invest their time. "Grab five things before five others: your youth before your decrepitude, your health before your illness, you leisure before your work, and your life before your death." (Alhakim, p341).

The Prophet also suggested the benefit of rising early. " Rise early to earn your living and do your affairs, for it brings about blessing and success." (SahihAlbuckari)

Table 1: Islam Usage of Five in Time Management

\begin{tabular}{||l|l|l|l||}
\hline \hline 5 PILLARS & 5 PRAYERS & QUESTIONS & FIVE BEFORE FIVE \\
\hline Shahadah, confession of faith & Dawn - Fajr & How he spent his lifetime & $\begin{array}{l}\text { Your youth before your } \\
\text { decrepitude }\end{array}$ \\
\hline Salah, prayer & Mid day - Zuhr & How he spent his youth & Your health before your illness \\
\hline Zakhat - almsgiving & Afternoon - Asr & $\begin{array}{l}\text { From where he acquired } \\
\text { his wealth }\end{array}$ & Your leisure before your work \\
\hline Ramadan, fasting & Dusk - Maghrib & How he spent it & Your life before your death \\
\hline Hajj, Pilgramage & Night - Isha & $\begin{array}{l}\text { What he did with his } \\
\text { knowledge }\end{array}$ & Rise early to make your living \\
\hline
\end{tabular}

Resource: Islam Usage of Five in Time Management(Shmailan,2014)

In summary, managing time is a very important part of any Muslim's life and has been discussed in the Qu'ran and many of the Hadiths. Time management is related to prayer, business, family and leisure. It is part of the five pillars of Islam. The advice is practical as well as religious and can be used as a basis for effective time management for any Muslim.

\section{Saudi Sample Field Study 2014:}

In2014 field studies were conducted on Time Management in the eastern region Saudi Arabia. The respondents were employees of Saudi national staff working in private firms. All of them were male. There were 223 people surveyed. The respondents were segmented by age, whether or not they were married, their education level and years of experience working. The key focus of the study was the time wasted due to smoking in the work place and its effect on productivity. 


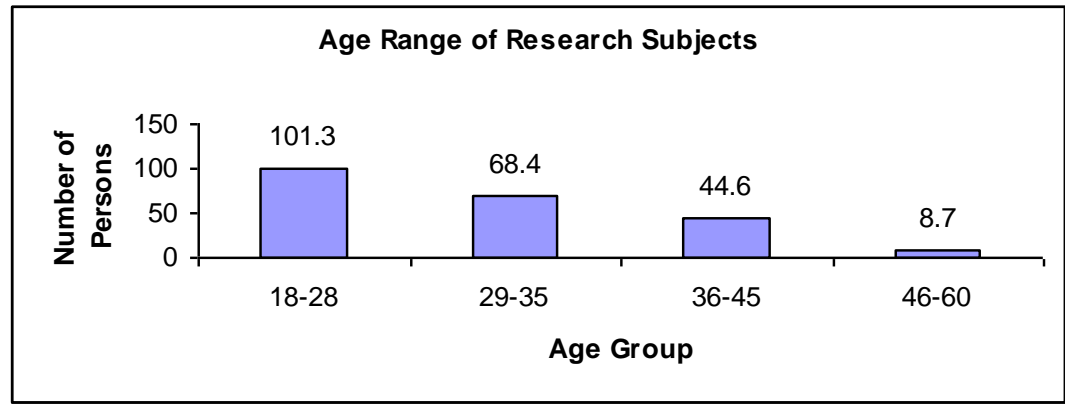

The research subjects varied in their ages. Of the respondents $45 \%$ were between the ages of 18-28, $30 \%$ were between the ages of 29-35, 20 were between the ages of 36-45 and 5\% were between the ages of 4660. That means that $75 \%$ of those respondents were under the age of 36 , making the majority of subjects fairly young.

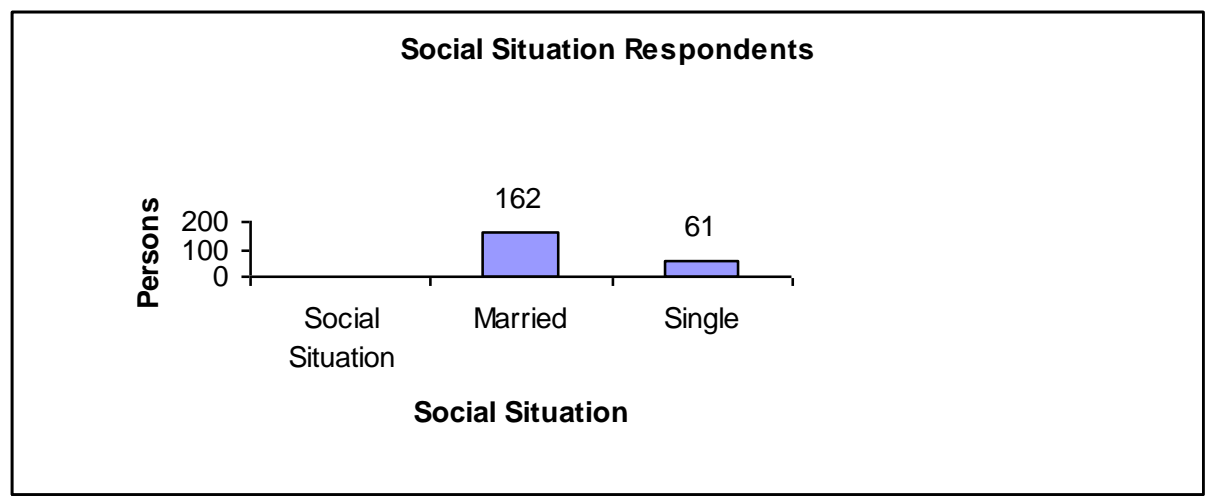

The respondents were then asked weather they were married or not. The majority of them $73 \%$ were married with the remainder $27 \%$ not married.

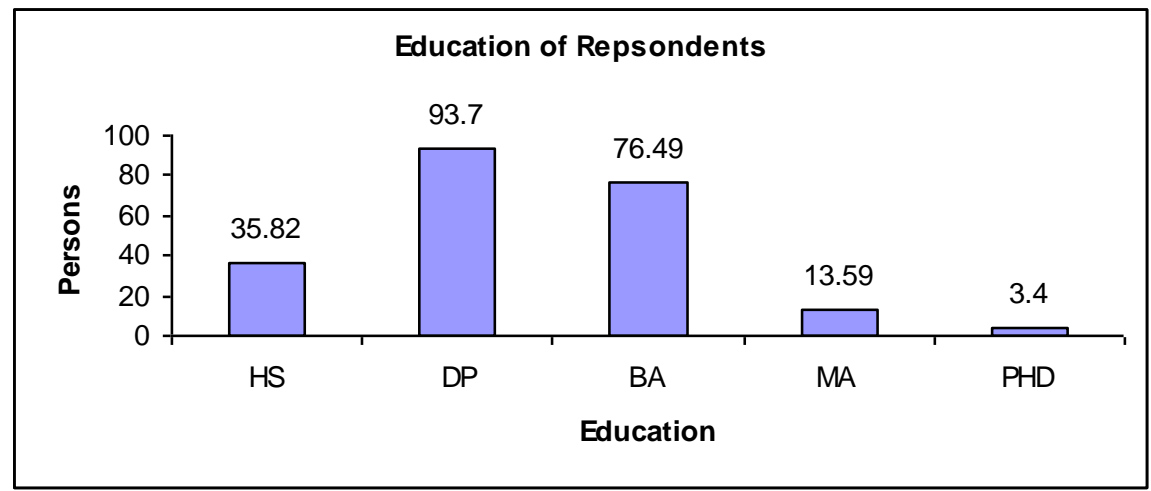

Most of the respondents were educated beyond high school. The respondents with diplomas were $42 \%$, those with BA degrees were 34\%, those with MA degrees were 6\% and 2\% had PHD's.

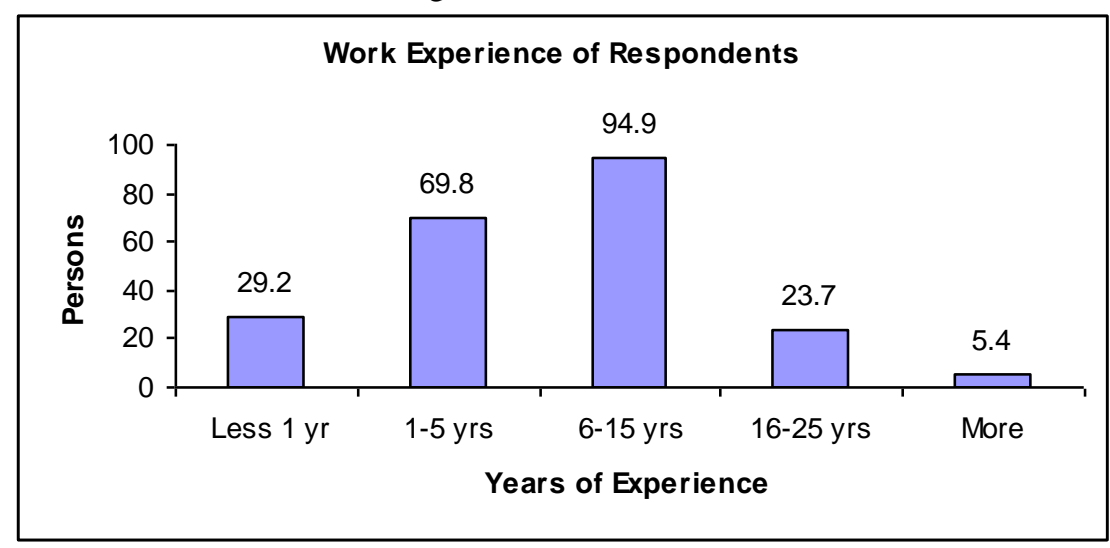


All of the respondents had work experience and were currently working. Many of the respondents had worked less six years with $31 \%$ under a year and $31 \%$ up to five years. The largest number of respondents had 6-15 years at $43 \%$. The lower categories were $16-25$ years at $6 \%$ and $2 \%$ with more than 25 years experience.

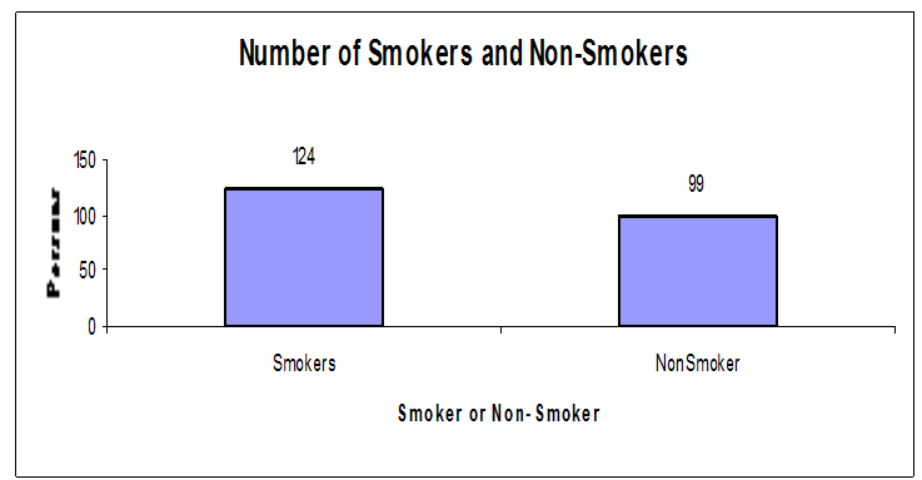

With the main focus on time wasting on smoking in the work force the respondents were divided into smokers and non smokers. In the chart below the majority of those interviewed were smokers making up 56\% of the total. The remaining were non smokers representing $44 \%$.

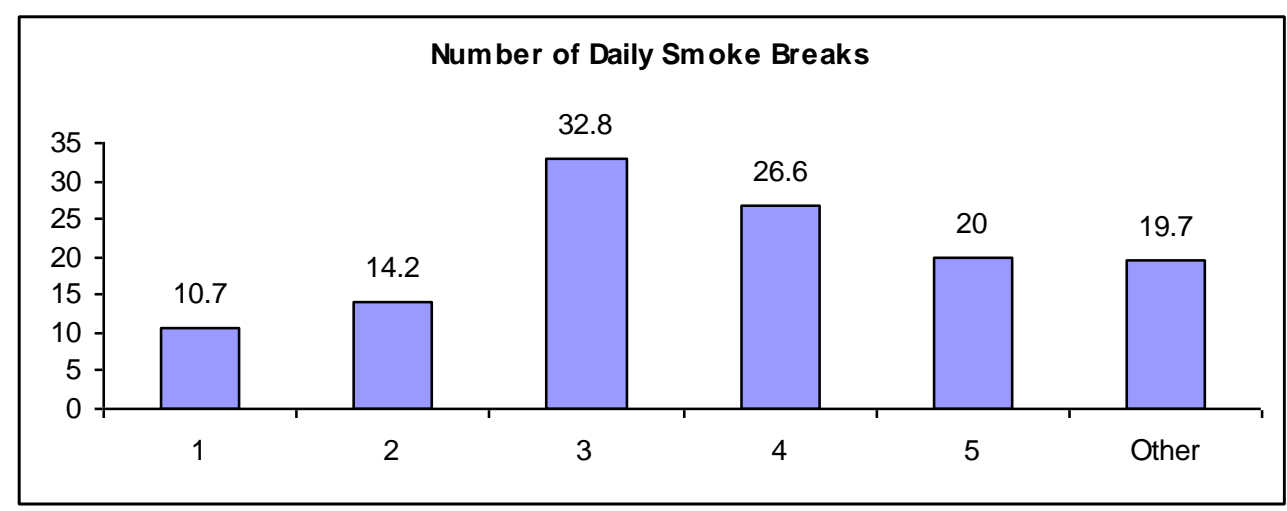

The smokers were asked how many smoke breaks they take daily. Only $20 \%$ took between one and two breaks. The majority, $47 \%$ took between three and four breaks. Finally $32 \%$ took five or more smoke breaks.

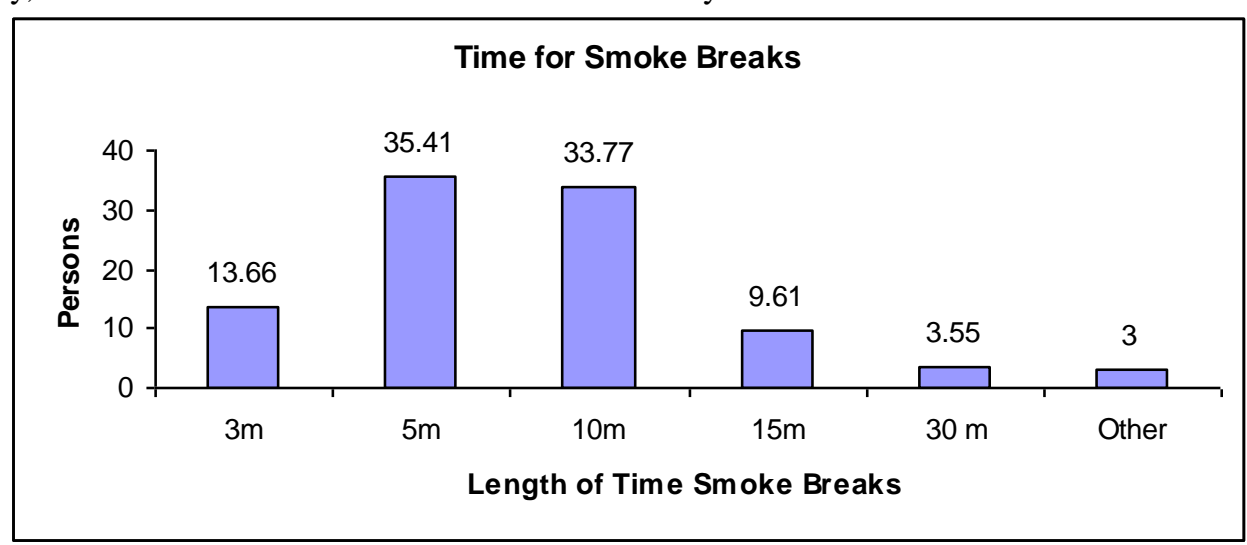

The above chart refers to the length of each smoke break. The lowest time mentioned by $14 \%$ of the respondents was three minutes. The majority, 70\%, of breaks fell into the 5-10 minute range. The smaller categories were 15 minutes at 10\%, 30 minutes at $4 \%$ and then $3 \%$ in the other range.

By examining the two charts if $47 \%$ took between three and four breaks and $70 \%$ took between 5 and 10 minutes for each break smoking employees could take on the low end three breaks for 5 minutes for a total of 15 minutes or at the high end 4 breaks for 15 minutes for 1 hour. If they take an hour a day, in one week they wasted 5 hours and in one month they waste 20 hours. So half of one work week productivity is lost a month due to smoking. For the year that can add up to 240 hours a year or 30 days a year. That means the smoker can lose productivity equivalent to a month and a half of work a year. 


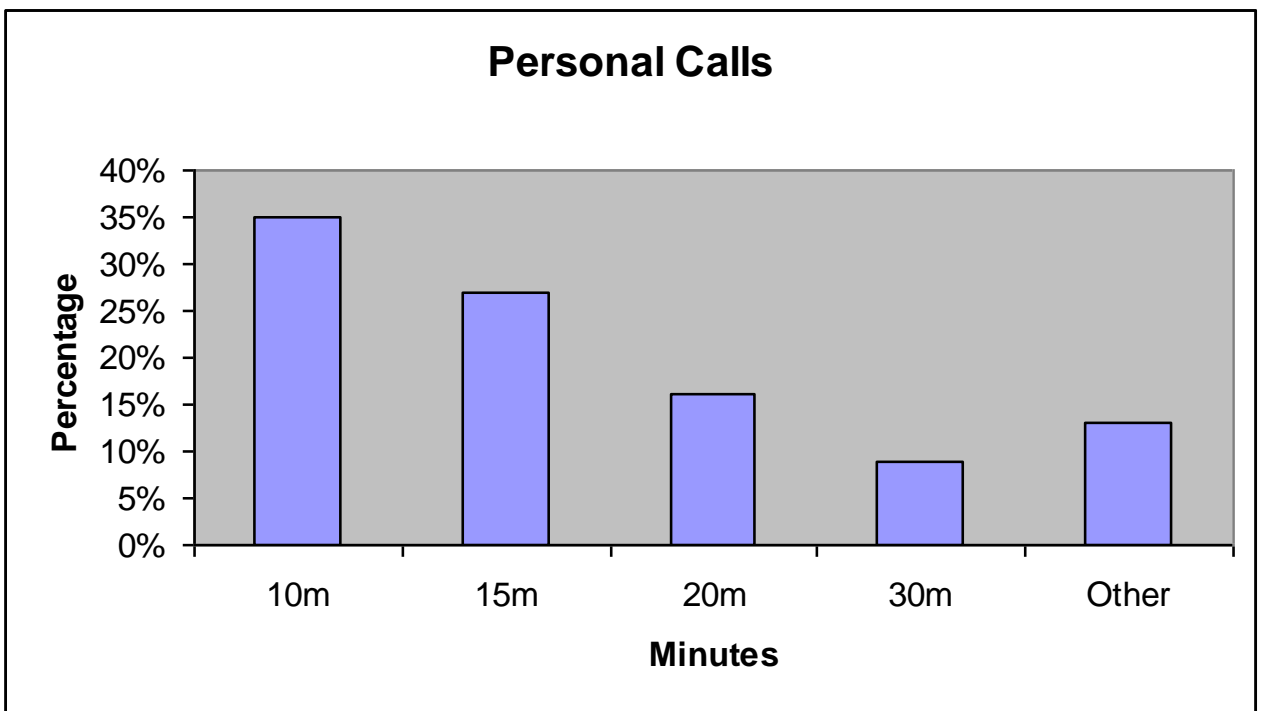

Respondents were also asked how much time they spent on personal phone calls at work. Of the top two categories, $35 \%$ of the respondents said they spent 10 minutes on personal calls and $27 \%$ said 15 minutes. Those who talked 20 minutes were $16 \%$ and 30 minutes $9 \%$. The final category Other was $13 \%$.

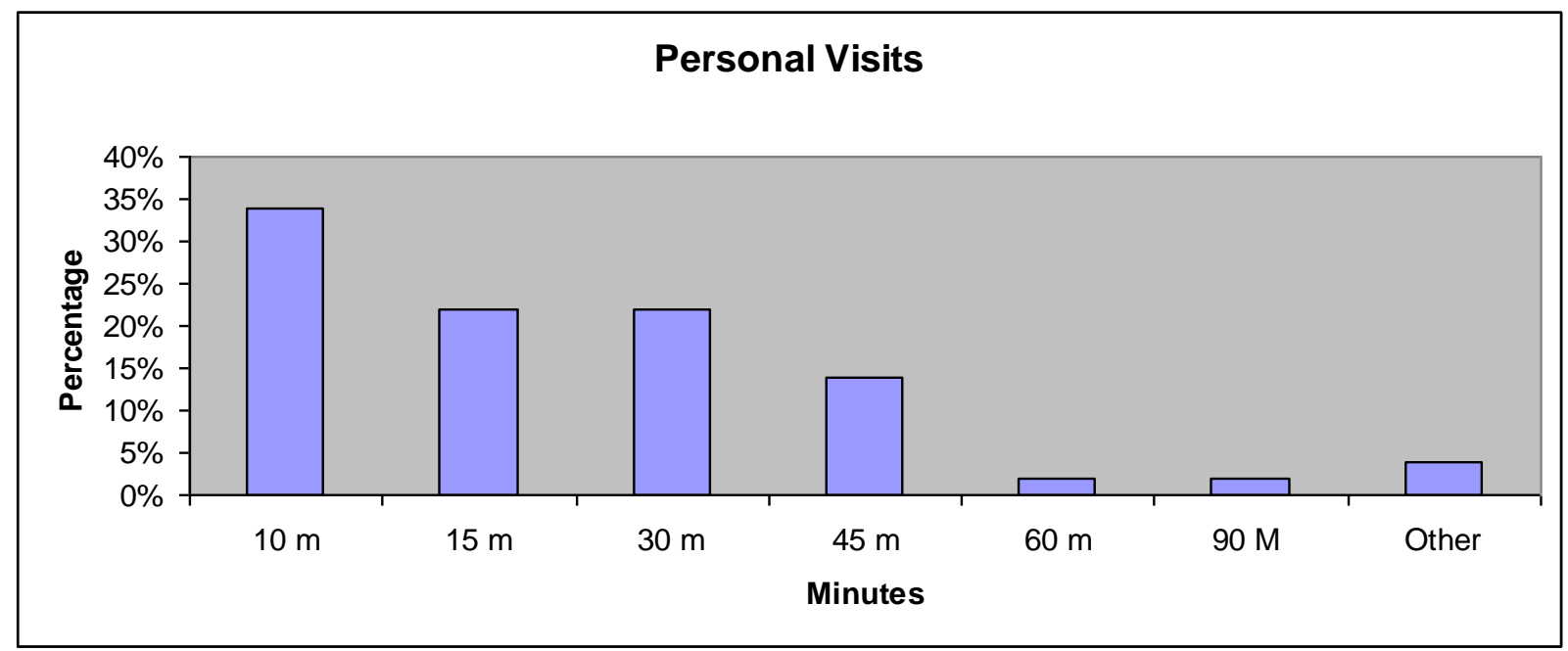

Another category the respondents were asked was how much time they wasted on personal visits at work. In the first two categories 34\% said they spent 10 minutes on personal meetings and 22\% said 15 minutes. Those who spent 30 minutes were $22 \%$ and for 45 minutes 14\%. The last three categories 60 minutes, 90 minutes and Other were a total of $8 \%$.

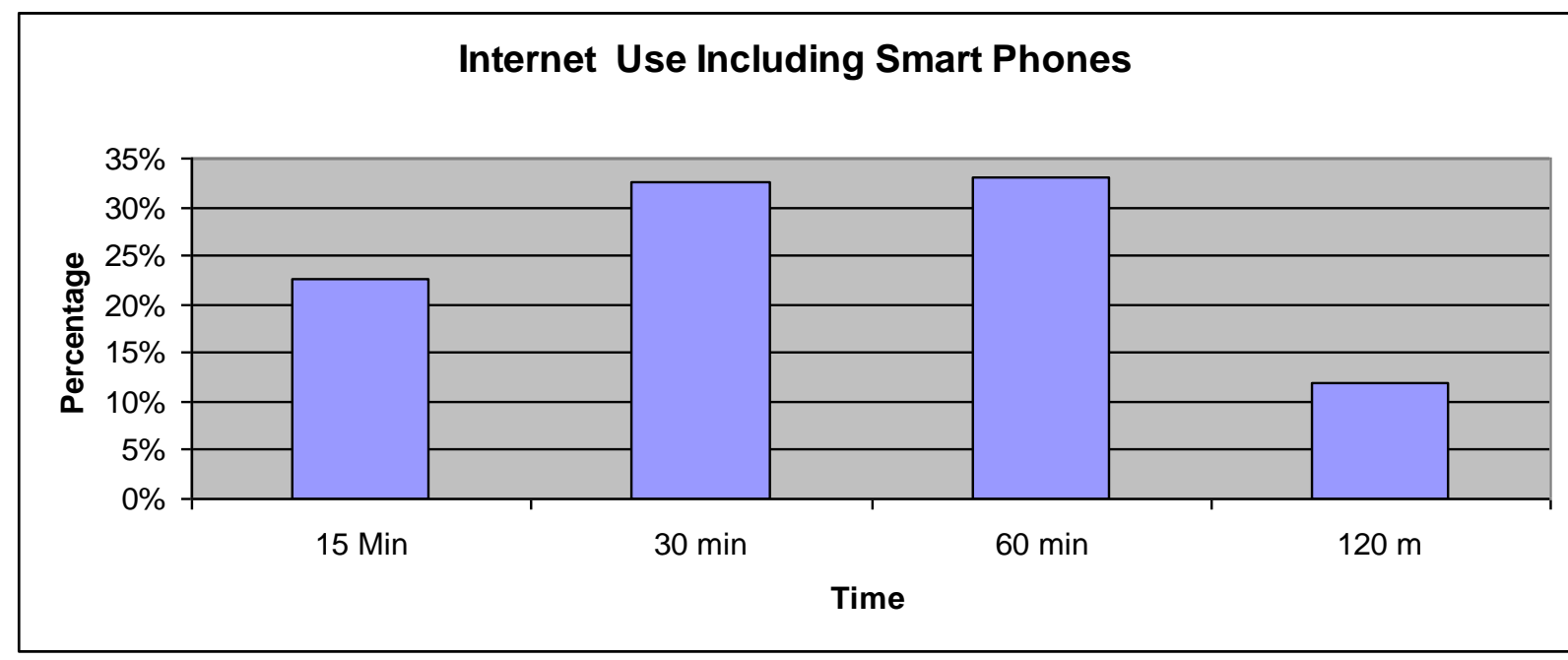


Internet and Smart Phone usage at work is a problem all over the world. The respondents of the survey were asked how much time they spent on internet related tasks when they were at work. Twenty three percent of respondents said that they spent 15 minutes on internet use at work. The majority of respondents, 66\% spent between 30 and 60 minutes on internet usage at work. The final category, 120 minutes or more represented $12 \%$ of the respondents. It is clear from this part of the survey that employees waste a great deal of time on the internet.

The surveys revealed that there was time wasted in Saudi organizations and in some cases that could be a large amount of time in a day. For example if someone took 3 smoke breaks a day for 5 minutes each, had personal calls for 10 minutes, personal visits of 10 minutes and internet usage of 60 minutes they would waste time for 1.5 hours a day. If they took wasted more time taking 5 smoke breaks at 10 minutes each, personal calls of 20 minutes, personal visits at 45 minutes and 60 minutes they would waste a total of 2.9 hours a day. On the high end if they took five smoke breaks for 30 minutes each, personal calls of 30 minutes, personal visits of 45 minutes and internet of 120 minutes they would waste 5.75 hours a day.

\section{Conclusions:}

Time wasting costs organizations around the world billions and billions of dollars every year and can contribute to loss of productivity, mistakes and accidents. Studies in the USA indicate that over 2 hours a day is wasted on average by US employees. A recent study conducted in higher rate of time is wasted in Saudi Arabia than in the US. Employees waste time in meetings, smoking, surfing the internet, smart phones, personal calls and chatting. If a Saudi employee wastes 4 hours a day, that is 20 hours a week, 80 hours a month, and 960 hours a year or 120 days. This is a huge waste for government and business.

Saudi Arabia is the cradle of Islam and practicing the tenants of Islam is inherent in the culture. There are a number of references in the Holy Quran that talk about the effective use of time in a person's lifetime. The connection between the Quran and managing time effectively is a relatively unknown concept. In a society that every day life is related in terms of Islam, there may be a need to adopt both a religious and organizational perspective in order to improve the use of time in organizations. For the individual effective time management can then be seen closely related to Islam and another way to practice the religion better. Islam references to time management can be used as a tool to motivate Saudi employees to reduce their time wasting and make organizations more productive.

\subsection{Recommendations:}

It is clear that their needs to be improvements in how Saudi employees manage their time. The amount of time wasted is causing organizations a significant loss in productivity and profitability. The references in the Holy Quran and Hadiths on the Muslim managing their time effectively could be a key motivator for Saudi employees to reduce their time at work. This connection between time management and Islam is a great tool for getting the message across.

In order to reduce the time wasted and help Saudi employees practice their religion better would require a number of actions. Below is a list of recommendations that could move the process forward:

1. Develop motivational material that would encourage more effective time management for Muslims.

2. Develop training materials that blend time management and Islam.

3. Find large organizations that are willing to participate in a pilot program reduce time wasting at work.

4. Conduct pilot training sessions and record the improvements in productivity for those who attended the training sessions.

5. Produce an academic paper on the findings of such a pilot and publish it.

6. Encourage other organizations to use the materials to train their organizations.

7. Connect time management to employee yearly goals.

\section{References:}

[1]. Attabarani, Abu qassim, AlmujamAlkhabeer (The great dictionary), Vol(20). P61

[2]. Altarmidthi, Abu -Essa, sunnahattermidhi, op,cit,Book No38, ch1, Vol(4).p612. Hadith No.2417

[3]. Al-hakim, M:Almustadrak, Book No:7846,v(4).p341

[4]. Alexander, R \& Dobson, M.S. (2008) .Real-world time management. AMACOM

[5]. Becker, H \&Mustric, F.(2008). Can I Have 5 Minutes of Your Time?" Morgan James Publishing

[6]. Bhugra, D. \&Howes, O.(2007) .Handbook of Psychiatric Trainees. RCPsych Publications

[7]. Brott, R. (2008) .Successful Time Management: Be the Productive Person You Want to Be ANC Book Publishing

[8]. Cashell, B.W. (2004). Productivity and wages.Federal Publications.193: Retrieved from

[9]. Dan, M. (2005). Wasted time at work costing companies billions. Asian Enterprise

[10]. Drezner, D. (2005).Weighing the scales: The Internet"s effect on state-society relations. Paper presented March 2005 at conference: "Global Flow of Information," Yale Information Society Project, Yale Law School. Retrieved from http://islandia.law.yale.edu/isp/GlobalFlow/paper/Drezner.pdf. 
[11]. Facebook. (2010).captures top spot among social networking sites in india Retrieved from http://www.comscore.com/Press_Events/Press_Releases/2010/8/Facebook_Captures_Top_Spot_among_Social_Networking_Site s_i n_India.

[12]. Forsyth, P. (2010) "Successful Time Management” Kogan PageGaudin, S. (2009). Companies ban Facebook, Twitter at Work.

[13]. Gouveia, A. (2012). Wasting time at work 2012. Retrieved from: http://www.salary.com/wasting-time-at-work-2012/

[14]. Green, P \& Skinner, D. (2005). Does time management training work? An evaluation" International Journal of Training and Development. Volume 9( 2), $124-139$.

[15]. Harris, J. (2009). Time Management 100 Success Secrets: The 100 Most Asked Questions on Skills, Tips, Training, Tools and Techniques for Effective Time Management" Lulu Publications

[16]. Hartshorn, K. (1997). The humane workplace is a productive workplace. National Productivity Review, $16(2), 1-7$.

[17]. Kisiel, R. (2009). Town hall bans staff from using facebook after they waste 572 hours in one month. Retrieved from http://www.dailymail.co.uk/news/article-1210361/Town-hall-bans-staff-using-Facebook-waste-572-hours-month.html.

[18]. Limoncelli, T. (2006) "Time management for system administrators" O’Reilly

[19]. Mancini, M. (2007). Time Management: "24 Techniques to Make Each Minute Work" McGrow-Hill

[20]. Marquis, B. L. \& Huston, C. J. (2009). Leadership Roles and Management Functions in Nursing: Theory and Application. 6th Edition. Lippincott Williams \&Wilkias. 530 Walnut Street, Philadelphia, United States.

[21]. McKinsey Global Institute(2012).The social economy: Unlocking value and productivity through social technologies.

[22]. Mudrack, P. E. (1997). The structure of perceptions of time" Educational and Psychological Measurement, 57, 222-240

[23]. Rivera, C. (2007).Time Management. Global Media

[24]. Sahih Al-buckari,op.c.t., Book78, ch84

[25]. Schroeder, s. (2010). Social networks are becoming a security risk [SURVEY]. Retrieved February 25, 2011 from World Wide Web:

[26]. Seaward, B.L \& Seaward, B. (2011). "Managing Stress: Principles and Strategies for Health and Well-Being” Jones and Bartlett Learning

[27]. Seaward, B.L. (2011) "Essentials of Managing Stress" Jones and Bartlett Learning

[28]. Snapshot Spy.(2008). Computer \&Internet Statistics.Retrieved from http://www.snapshotspy. com/stats.htm\#employee Southwest of England Regional Development Agency. (2005). Meeting the productivity challenge. Retrieved fromeconomy.swo.org.uk/EasySiteWeb/GatewayLink.aspx?alId=45188 WebSpy.(2002). Internet Use Statistics. Retrieved from http://www.webspy.com/resources/whitepapers/InternetUseStatistics.pdf

[29]. Sophos (2010). Malware and spam rise $70 \%$ on social networks, security reportreveals. Retrieved July 11, 2011, from w.w.w://pr.webroot.com/En_US/ about-press-room-press-releases-web-2-0-istop-security-threat-to-SMBs-in-2010.html

[30]. Webroot Software, Inc. (February 2010). New Webroot survey shows Web 2.0 is top security threat to SMBs in 2010. Retrieved March 8, 2011, from World Wide

[31]. Wu, D. (2009).Temporal Structures in Individual Time Management: Practices to Enhance Calendar Tool Design. IGI 